\title{
Webservice Learning Preparation Report Polytechnic Indonusa Surakarta
}

\author{
Edy Susena ${ }^{1, *}$, Dwi Iskandar ${ }^{2}$, Muhammad Hari Wahyudi ${ }^{3}$ \\ ${ }^{1,2,3}$ Sistem Informasi \\ 1,2,3 Politeknik Indonusa Surakarta \\ 1,2,3J1. K.H Samanhudi No. 31, Surakarta, Indonesia \\ 1'edysusena@poltekindonusa.ac.id, 2dwik@poltekindonusa.ac.id, ${ }^{3}$ muhammad.wahyudi@ poltekindonusa.ac.id
}

\begin{abstract}
Polytechnic Indonusa Surakarta is a private university that has various study programs available. Some of the study programs must report learning preparation reports every semester which must be submitted and validated directly by Deputy Director I as an academic field. At first these activities were carried out manually and not yet computerized so as to facilitate program studies in conducting consultations and Deputy Director I who had a busy schedule but had to validate manually. This system was created with the aim of making it easier for Polytechnic Indonusa Surakarta side in collecting file, conducting consultation, signing signatures, and making learning preparation reports. Data collection methods used include the method of literature study, observation, interviews and documentation. This system will use a MySQL database with the PHP programming language with the Laravel framework. The method used in making this web service is the waterfall method. The result of the webservice learning preparation report is that the webservice system can facilitate both study programs in submitting and conducting consultations and Deputy Director I in conducting validation, consulting, and preparing learning preparation reports. This system will store data from reports that are entered into the webservice database.
\end{abstract}

Keywords—Webservice, System, Study Program, Polytechnic, Indonusal

\section{INTRODUCTION}

In the era of globalization, technological advances are developing very rapidly, indirectly affecting all aspects of human life. Technological developments require that various agencies, both government agencies, private and organizations, must improve themselves in responding to these technological developments.

Polytechnic Indonusa Surakarta is a private university that has various study programs available, namely: D3 Information Systems, D3 Automotive Engineering, D3 Mass Communication, D3 Pharmacy, D3 Hospitality, and S1 Applied Health Information Management. Some of these study programs must report a learning preparation report in each semester which must be submitted and validated directly by the Deputy Director I as the academic field. At first these activities were carried out manually and not yet computerized, making it difficult for both the study program to conduct consultations and the Deputy Director I who had a busy schedule but had to manually validate. In addition, during the current covid-19 pandemic, it would be better if interactions between individuals could be reduced and renewed by using technology media.

Therefore, with the creation of a Learning Preparation Report Webservice, it is hoped that the webservice system can facilitate both study programs in submitting and conducting consultations and Deputy Director I in conducting validation. In addition, this webservice can store data from the entered reports, so that these reports will be stored properly in the webservice database.

\section{RESEARCH METHODS}

SDLC model waterfall (waterfall) is often also called a linear sequential model (linear sequential) or classical life cycle (classic life cycle). The waterfall model provides a sequential software lifeflow approach starting from analysis, design, coding, testing, and support stages.

\subsection{Software Requirements Analysis}

The process of gathering requirements is carried out intensively to specify software requirements so that users can understand what kind of software is needed by the user. Software requirements specifications at this stage need to be documented.

\subsection{Design}

Software design is a multi-step process that focuses on the design of a software program including data structures, software architecture, interface representations, and coding procedures. This stage translates software requirements from the requirements analysis stage to a design representation so that it can be implemented into a program at a later stage. The software design produced at this stage also needs to be documented. 


\subsection{Code Generation}

Design programs must be translated into software programs. The result of this stage is a computer program in accordance with the design that has been made at the design stage.

\subsection{Test}

Testing focuses on the software logically and functionally and ensures that all parts have been tested. This is done to minimize errors and ensure that the output produced is as desired.

\subsection{Support or Maintenance (maintenance)}

It is possible for a software to change when it has been sent to the user. Changes can occur due to errors that appear and go undetected during testing or the software must adapt to a new environment. The support or maintenance phase can repeat the development process from specification analysis to changes to existing software, but not to creating new software [4].

\section{RESULT AND ANALYSIS}

\subsection{Running System}

In making a new information system, it is necessary to analyze the old system to be used as a guide. This is done to find the problems that will be faced in the manufacture of information systems. However, at the Polytechnic Indonusa Surakarta there is no system that is run to carry out the process of uploading documents and printing the entirety into a learning preparation report. The report generation process is still manual, namely:

1) Study Program Secretary: Prepares learning preparation reports based on data obtained from study program meetings, data from study programs, BAAK, and lecturers in charge of lectures.

2) Head of Study Program: Signs if the report is complete and good then the report is submitted to Deputy Director I for consultation and signature.

3) Deputy Director I: Approve the report, then the report is submitted to the Director for further consultation and if the report is good, a signature is affixed.

\subsection{Developed System}

The new system is a change from the previously used system. A system that is commonly used and converted into a special system is more structured. By utilizing technological developments, this can be realized by creating a Webservice Learning Preparation Report for the Polytechnic Indonusa Surakarta. The system to be created has advantages compared to the previous report generation process which was still done manually, namely:

1) Deputy Director I, Study Program, BAAK, and Lecturers: Can upload documents needed for report generation on Webservice.

2) Study Programs, BAAK, and Lecturers: Can consult each other through the notes column to provide notes on the uploaded document file whether there is a revision or not.

3) Director, Deputy Director I, and Study Program: Can validate the document if the document is complete and has been approved.

4) Director, Deputy Director I, Chair and Secretary of the Study Program: Can put a signature on the Webservice to be included on the report ratification page.

5) Deputy Director I and Study Programs: Can add a new academic year and semester and change the profile of the study program to be input in the report.

6) Director, Deputy Director I, and Study Programs: Can print learning preparation reports by combining uploaded documents into one along with cover and validation pages.

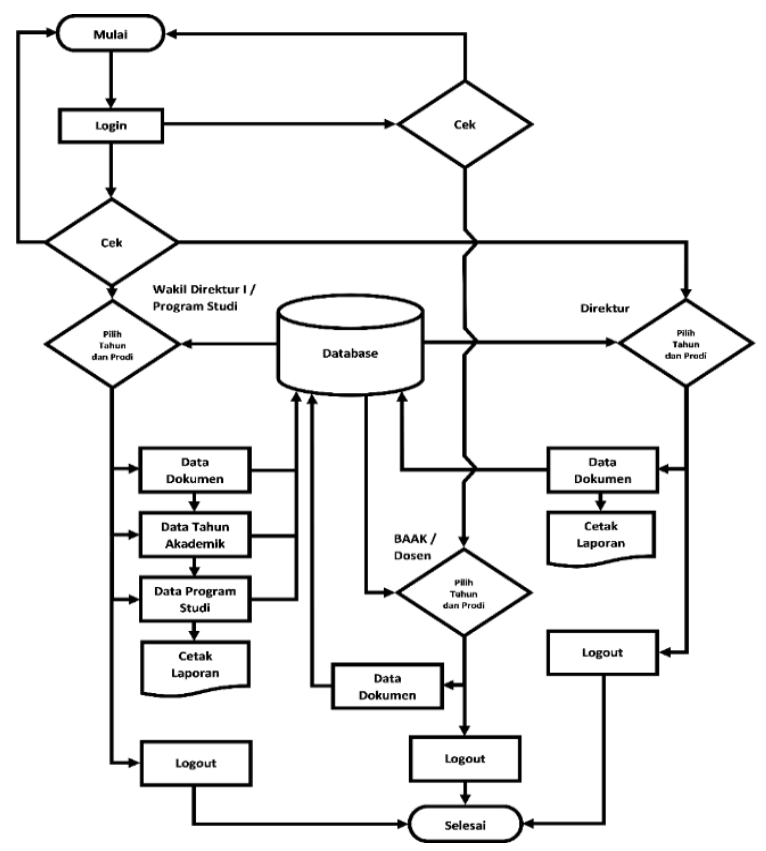


Figure 1. Flowchart of the system to be developed

\subsection{System Design}

The system design in the workbook (Susena, 2016) is a design that is carried out after the complete requirements have been collected. This stage is done before coding and aims to provide an overview of what should be done and how it will look.

1) Context Diagram: is a global picture of a system. In the context diagram describes the outline of the relationship between the entities that exist in the system.

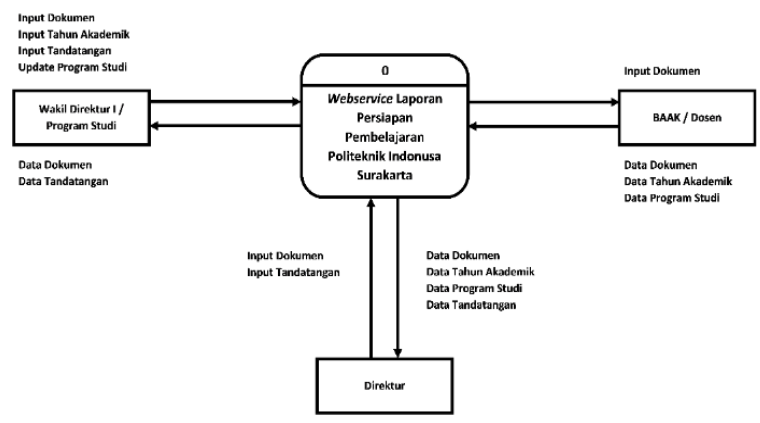

Figure 2. Context Diagram Design

2) Tiered Diagram: Describes the arrangement of processes starting from the top level, to a level where no existing processes are found.

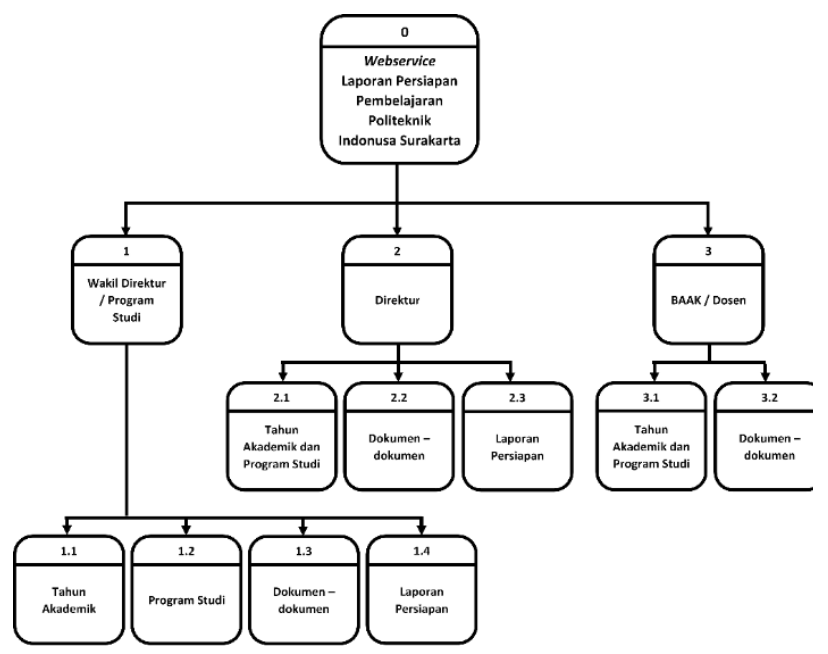

Figure 3. Tiered Diagram Design

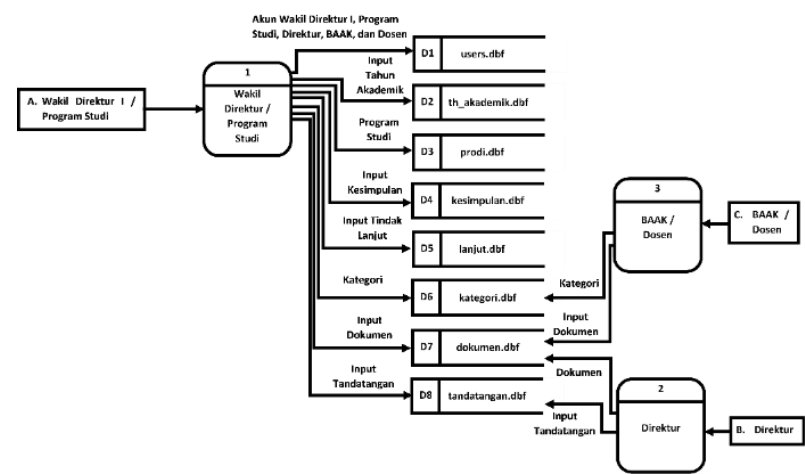

Figure 4. DAD Level 0

4) DAD level 1 Deputy Director I and Study Programs: Clarify the processes under DAD level 0. Explain document monitoring from beginning to end.

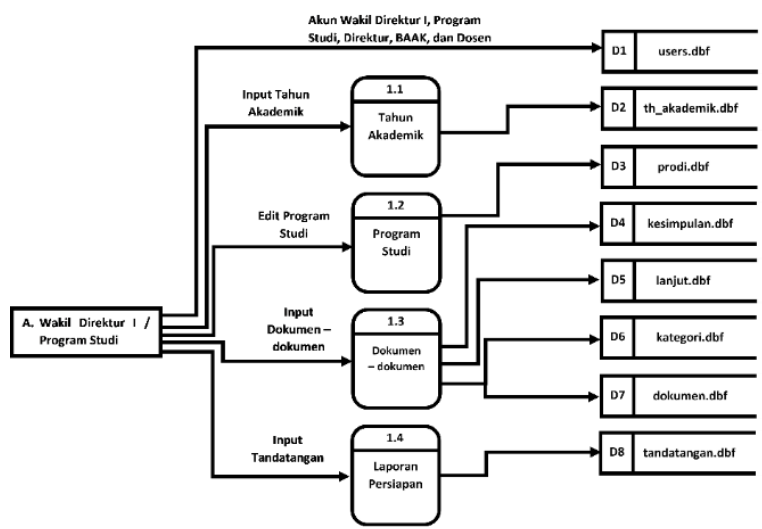

Figure 5. DAD Level 1 Deputy Director I and Study Program

5) DAD level 1 Director: Describes the data input flow process that occurs in the system with Director access rights.

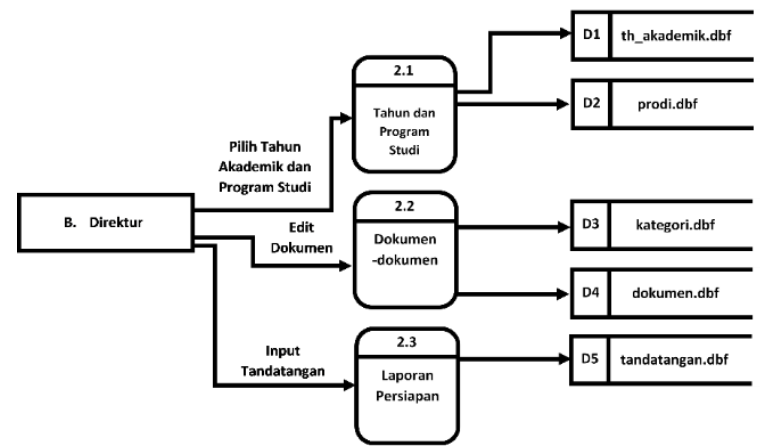

Figure 6. DAD Level 1 Director

3) Data Flow Diagram (DAD) level 0: Describes the overall flow of data. 
International Journal of Computer and Information System (IJCIS)

Peer Reviewed - International Journal

Vol : Vol. 02, Issue 04, November 2021

e-ISSN : 2745-9659

https://ijcis.net/index.php/ijcis/index

6) DAD level 1 BAAK and Lecturers: Clarify the process under DAD level 0 for BAAK and Lecturers.

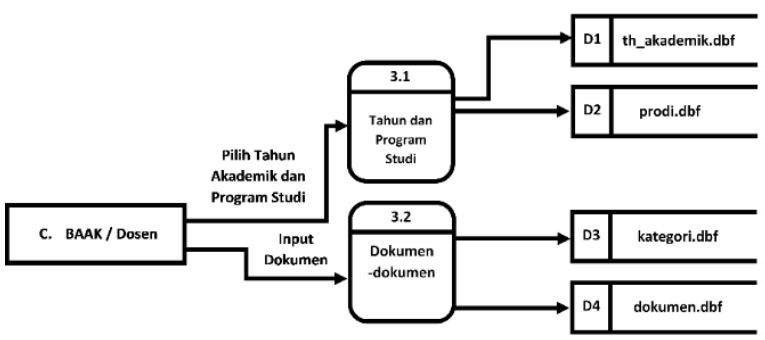

Figure 7. DAD Level 1 BAAK and Lecturers

\subsection{Table Relation}

The table relation for developing Web Service Learning Preparation Report Polytechnic Indonusa Surakarta is as follows:

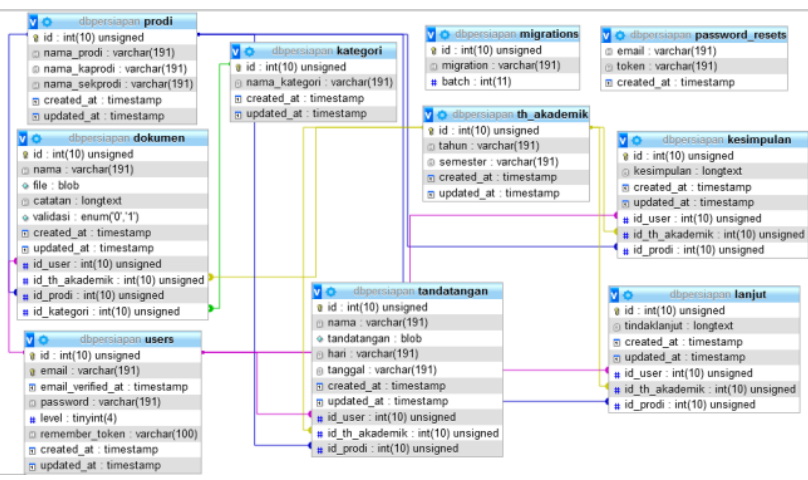

Figure 8. Table Relation

\subsection{Program Testing}

The test design that will be carried out on this website uses the black box method. Black box testing focuses on system functions. This method is used to determine whether the system is functioning properly and correctly.

Table 1. Program Testing with the Black Box Method

\begin{tabular}{cclc}
\hline No & Interface & Type of Unit Tested & Result \\
\hline 1 & Login Menu & Enter email for & Success \\
& & Deputy Director I & \\
& & access rights, & \\
& & namely: & \\
& & wadir1 @ localhost.co & \\
\hline
\end{tabular}

\begin{tabular}{|c|c|c|c|}
\hline No & Interface & Type of Unit Tested & Result \\
\hline & & $\begin{array}{l}\text { m dan password: } \\
\text { Wadir1123 }\end{array}$ & \\
\hline 2 & Login Menu & $\begin{array}{l}\text { Enter email for Study } \\
\text { Program access } \\
\text { rights, namely: } \\
\text { prodi @ localhost.com } \\
\text { and password: } \\
\text { Prodi123 }\end{array}$ & Success \\
\hline 3 & Login Menu & $\begin{array}{l}\text { Enter the email for } \\
\text { the Director's access } \\
\text { rights, namely: } \\
\text { direktur@ localhost.c } \\
\text { om and password: } \\
\text { Direktur123 }\end{array}$ & Success \\
\hline
\end{tabular}

4 Login Menu $\quad$ Enter the email for $\quad$ Success BAAK access rights, namely: baak@localhost.com and password: Baak123

\begin{tabular}{lll}
\hline 5 Login Menu & Enter email for & Success \\
& Lecturer access & \\
& rights, namely: & \\
& dosen @ localhost.co & \\
& m and password: & \\
& Dosen123 & \\
\hline
\end{tabular}

6 Login Menu Choose an academic Success year and study program

7 Study Program Choose an academic Success Selection Menu year and study program

\begin{tabular}{ccll}
\hline 8 & $\begin{array}{c}\text { Director } \\
\text { Selection Menu }\end{array}$ & $\begin{array}{l}\text { Choose an academic } \\
\text { year and study } \\
\text { program }\end{array}$ & Success \\
& & & \\
\hline 9 & BAAK & $\begin{array}{l}\text { Choose an academic } \\
\text { Selection Menu }\end{array}$ & Success \\
& & \\
& & \\
& & \\
\hline 10 & Lecturer and study & Choose an academic & Success \\
& Selection Menu & year and study & \\
& & program & \\
\hline 11 & Menu for & View, add, delete & Success \\
Academic Year & academic year & \\
Deputy & & \\
Director I & &
\end{tabular}


International Journal of Computer and Information System (IJCIS)

Peer Reviewed - International Journal

Vol : Vol. 02, Issue 04, November 2021

e-ISSN : 2745-9659

https://ijcis.net/index.php/ijcis/index

\begin{tabular}{cccc}
\hline No & Interface & Type of Unit Tested & Result \\
\hline 12 & Menu for & View, add, delete & Success \\
& $\begin{array}{c}\text { Academic Year } \\
\text { of Study } \\
\text { Program }\end{array}$ & & \\
& & & \\
& &
\end{tabular}

13 Menu Profile Viewing, changing Success Study Program the profile of the Deputy study program Director I

\begin{tabular}{rrlr}
\hline 14 & Menu Profile & Viewing, changing & Success \\
Study Program & the profile of the & \\
Study Program & study program & \\
\hline
\end{tabular}

\begin{tabular}{|c|c|c|}
\hline 15 & $\begin{array}{c}\text { Deputy } \\
\text { Director I. } \\
\text { Document } \\
\text { Menu }\end{array}$ & $\begin{array}{l}\text { View, add, validate, } \\
\text { annotate, delete } \\
\text { documents }\end{array}$ \\
\hline
\end{tabular}

16 Study Program View, add, validate, Success Document annotate, delete Menu documents

\begin{tabular}{ccll}
\hline 17 & $\begin{array}{c}\text { Director's } \\
\text { Document } \\
\text { Menu }\end{array}$ & $\begin{array}{l}\text { View, validate, } \\
\text { provide document } \\
\text { records }\end{array}$ & Success \\
\hline 18 & $\begin{array}{c}\text { BAAK } \\
\text { Document } \\
\text { Menu }\end{array}$ & $\begin{array}{l}\text { View, add, delete } \\
\text { documents }\end{array}$ & Success \\
& Lecturer & View, add, delete & Success \\
& Document \\
Menu & & \\
\hline 20 & Deputy & View, add, delete & Success \\
& $\begin{array}{c}\text { Director's } \\
\text { Signature } \\
\text { Menu }\end{array}$ & & \\
& & & \\
& &
\end{tabular}

21 Study Program View, add, delete Success Signature documents Menu

22 Director's View, add, delete $\quad$ Success Signature documents Menu

23 Print Report of Print Report (PDF) Success Deputy

Director I

24 Print Study Print Report (PDF) Success Program Report

25 Print Director's Print Report (PDF) Success Report

\subsection{Program Implementation}

The implementation of the program is carried out after completing the existing system testing by uploading the system using web hosting media at the agency.

\section{1) Academic Year and Study Program Menu}

This menu is used to select the academic year and study program to be displayed. Here's how it looks:

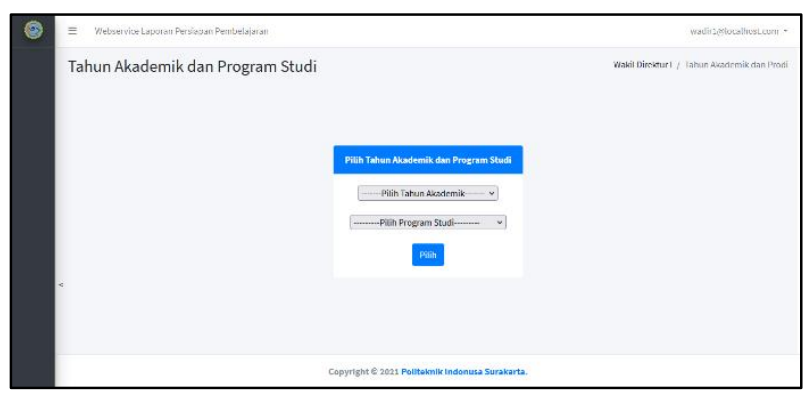

Figure 9. Display Select Academic Year and Study Program

2) Dashboard Menu

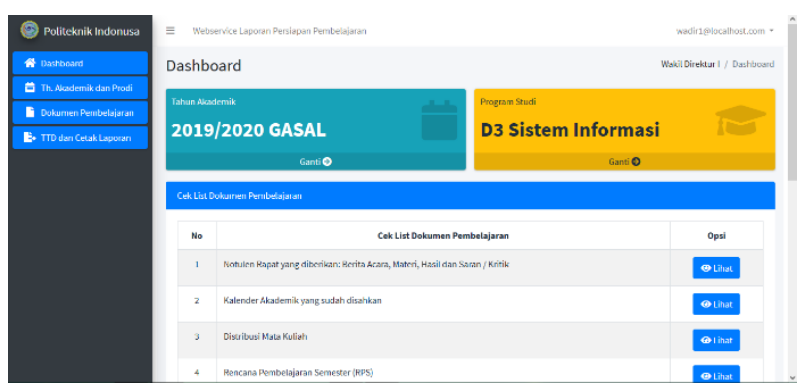

Figure 10. Dashboard menu

3) Document Menu

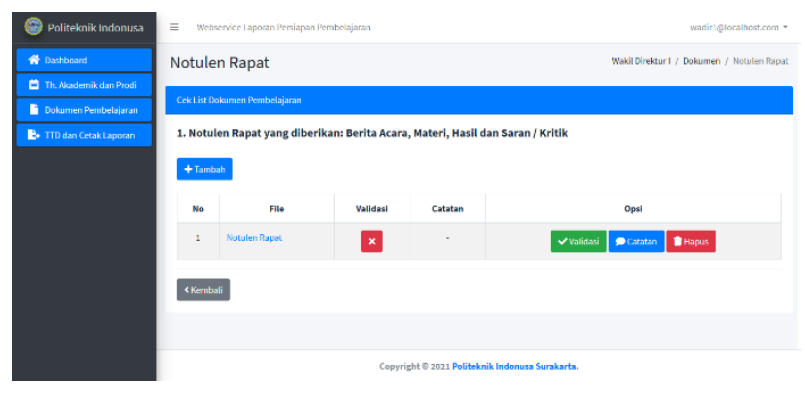

Figure 11. Document Menu 
4) Academic Year Menu

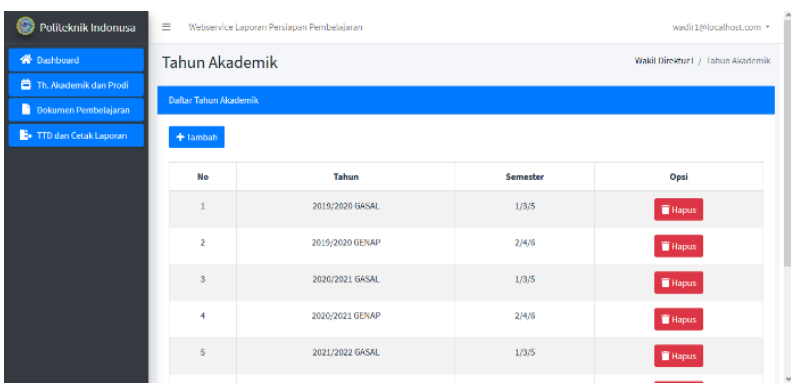

Figure 12. Academic Year Menu

\section{5) Study Program Menu}

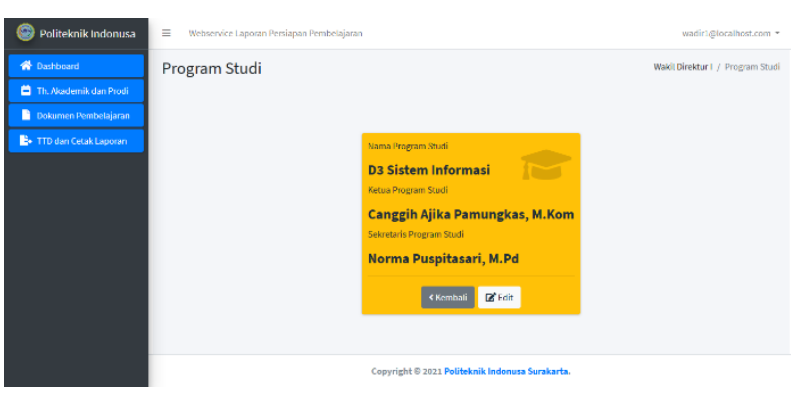

Figure 13. Study Program Menu

\section{6) Print Menu and Sign Report}

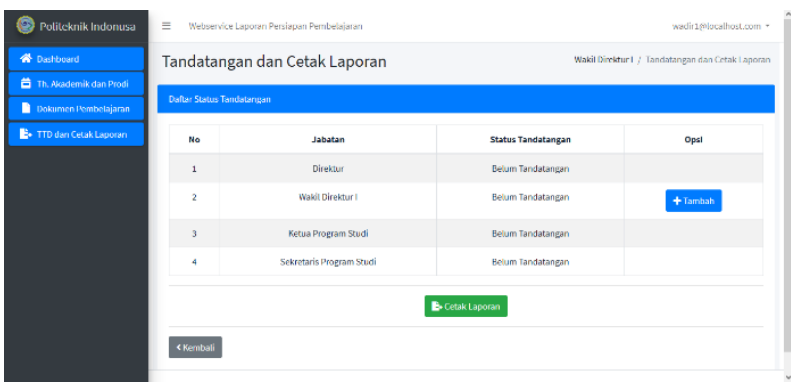

Figure 14. Menu Signature and Print Report

\section{CONCLUSION}

\subsection{Conclusion}

Based on the results of the discussions and descriptions that have been presented by the author with the Webservice Learning Preparation Report for the Polytechnic Indonusa Surakarta, the authors draw the following conclusions:

1) With this webservice system, it is hoped that it will make the management of learning preparation reports more efficient.
2) Deputy Director I, Study Programs, BAAK, and Lecturers can consult and collect files faster through the system.

3) Facilitate the Deputy Director and Study Program to make reports, conduct consultations, and give signatures.

\subsection{Suggestions}

In the Design of Webservice Learning Preparation Reports at the Polytechnic Indonusa Surakarta, suggestions are needed so that the system can run perfectly:

1) The use of the database is centralized to join SIAKAD (Campus Academic Information System) so that the academic year entered is in accordance with the academic year of SIAKAD's.

2) There is a need for maintenance or maintenance to ensure the system runs properly at all times.

3) Perform initial backup on the system so that the system can be restored safely if one day there is damage to the main system.

\section{THANK-YOU NOTE}

The authors also thank the International Journal of Computer and Information System (IJCIS) Team for taking the time to complete this template. So that it can be used properly by us and other writers to channel their knowledge through the Journal (IJCIS).

\section{REFERENCES}

[1] B. Priambodo, N. C. Wibowo, and A. B. Putra, "Sistem Pengelolaan Data Barang Berbasis Desktop," J. Sist. Inf. Dan Bisnis Cerdas, vol. 10, no. 2, pp. 18-33, 2017.

[2] A. A. G. Y. Paramartha, G. K. Suryaningsih, and K. Y. E. Aryanto, "Implementasi Web Service Pada Sistem Pengindeksan Dan Pencarian Dokumen Tugas Akhir, Skripsi, Dan Praktik Kerja Lapangan," JST (Jurnal Sains dan Teknol., vol. 5, no. 2, p. 818, 2017.

[3] A. Josi, "Penerapan Metode Prototyping Dalam Membangun Website Desa (Studi Kasus Desa Sugihan Kecamatan Rambang)," Jti, vol. 9, no. 1, pp. 50-57, 2017. 
International Journal of Computer and Information System (IJCIS)

Peer Reviewed - International Journal

Vol : Vol. 02, Issue 04, November 2021

e-ISSN : 2745-9659

https://ijcis.net/index.php/ijcis/index

[4] M. Tabrani and E. Pudjiarti, "Penerapan Metode Waterfall Pada Sistem Informasi Inventori PT. Pangan Sehat Sejahtera," Inkofar, vol. 1, no. 2, pp. 30-40, 2017.

[5] D. Saputra and R. F. Aji, "Analisis Perbandingan Performa Web Service Rest Menggunakan Framework Laravel, Django dan Ruby On Rails Untuk Akses Data Dengan Aplikasi Mobile ( Studi Kasus: Portal EKampus STT Indonesia Tanjungpinang )," vol. 2, no. Vii, pp. 17-22, 2018.

[6] S. Akbar and F. Latifah, "Implementasi Framework Laravel Pada Sistem Informasi Sekolah Menggunakan Metode Waterfall Berbasis Web," Jisamar, vol. 3, no. 4, pp. 4553, 2019.

[7] E. Susena, Analisis dan Desain Sistem (ANSI), 3rd ed. Yogyakarta: Deepublish, 2016.
[8] Jannah, N. F., \& Muqorobin, M. (2021) Analysis Of Kasir Applications In Sales Management Information Systems at ASRI Store. International Journal of Computer and Information System (IJCIS), 2(2), 40-44.

[9] Hikmah, I. N., \& Muqorobin, M. (2020). Employee Payroll Information System On Company Web-Based Consultant Engineering Services. International Journal of Computer and Information System (IJCIS), 1(2), 27-30.

[10] Muslihah, I., \& Muqorobin, M. (2020). Texture Characteristic of Local Binary Pattern on Face Recognition with PROBABILISTIC LINEAR DISCRIMINANT ANALYSIS. International Journal of Computer and Information System (IJCIS), 1(1), 22-26. 